\title{
A Survey on Students' Extracurricular English Learning Time and Spare Time Schedule in Independent College
}

\author{
Hui Liu \\ Xi'an Jiaotong University City College \\ Xi'an, China 710018
}

\begin{abstract}
In order to fully know about the daily English learning situation of independent college students as well as the students' after-school arrangements and to understand the students' current learning situation, to adjust the teaching and achieve better teaching results, this questionnaire is conducted. The questionnaire includes students' spare time allocation, English extracurricular learning time use and daily life issues, such as mobile phone use and work style. The questionnaire is conducted simultaneously in three different universities, and the results are compared and analyzed. From the results, the current learning status of independent college students is not optimistic. As an English teacher in basic public courses, in addition to trying to adjust their teaching to adapt to new teaching situations, it is also necessary to continuously stimulate students' interest and enthusiasm for learning and cultivate students' great learning beliefs and strategies.
\end{abstract}

Keywords-extracurricular time; English learning; teaching response; independent college

\section{INTRODUCTION}

As a language subject, methods of English learning are similar to that of our native language, but it is quite different from the science and engineering curriculum, either. Due to the characteristics of the subject, academic performance of the English and Chinese is more dependent on the extracurricular time and energy input of the students. Whether it is the study of vocabulary and grammar, or the understanding of the discourse, it is impossible to get better results without paying a certain amount of time and energy.

At present, due to the development of science and technology as well as the rapid development of information and technology, such as the information explosion and the emergence of electronic tools like television, computers, mobile phones, and ipad have changed people's lifestyles and learning styles. As contemporary college students in the country, they have a very high share of mobile phones and computers. In particular, the use of mobile phones has a huge impact on current classroom teaching. In addition to the classroom time, how much time students spend each day to learn, how much time should be spent to learn English, and whether the learning style has changed, have important reference significance for university teachers to adapt to the current new teaching form.

\section{THE QUESTIONNAIRE}

In order to understand the English learning situation of independent college students, this questionnaire was designed and 11 classes in the first and second year of an independent college in Xi'an were randomly selected to conduct a questionnaire. At the same time, questionnaires were also provided to students from a key university and a higher vocational school in Xi'an for comparison. A total of 600 questionnaires were sent out and 590 of them were screened for data analysis. The data analysis tool uses Excel 2016.

The questionnaire investigated students' spare time allocation, English learning time and English scores, mobile phone use time and mobile phone activities.

The results of the questionnaire are now shared as follows:

\section{A. English Learning After School}

The most interesting variable in the survey is how much time students spend learning English outside the classroom as well as whether the length of extracurricular study time is related to the grade.

TABLE I. DAILY ENGLISH STUdy TIME AND GRADES OF INDEPENDENT COLLEGE STUDENTS

\begin{tabular}{|c|c|c|c|c|c|}
\hline Learning time & $<30$ minutes & 30-60 minutes & 60-90 minutes & 90-120 minutes & $>120$ minutes \\
\hline Student number & $40 \%$ & $42 \%$ & $14.6 \%$ & $3.4 \%$ & 0 \\
\hline TEM4 scores & 379 & 388 & 393 & 383 & \\
\hline
\end{tabular}


TABLE II.

SURVEY OF ENGLISH STUdy TIME AND SCORES OF KEy UNIVERSITY STUdENTS

\begin{tabular}{clllll}
\hline \multicolumn{1}{c}{ Learning time } & $<\mathbf{3 0}$ minutes & $\mathbf{3 0 - 6 0}$ minutes & $\mathbf{6 0 - 9 0}$ minutes & $\mathbf{9 0 - 1 2 0}$ minutes & $>\mathbf{1 2 0}$ minutes \\
\hline Student number & $49.4 \%$ & $48.7 \%$ & $1.9 \%$ & 0 & 0 \\
Scores of the College Entrance Examination & 128 & 129 & 118 & & \\
\hline
\end{tabular}

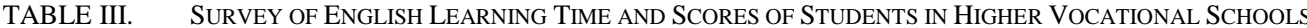

\begin{tabular}{|c|c|c|c|c|c|}
\hline Learning time & $<30$ minutes & 30-60 minutes & $60-90$ minutes & 90-120 minutes & $>120$ minutes \\
\hline Student number & $42.4 \%$ & $35.2 \%$ & $8.8 \%$ & $5.6 \%$ & $7.2 \%$ \\
\hline
\end{tabular}

From the data (see "Table I", "Table II" and "Table III") above, it can be seen that non-English majors spend less than one hour a day studying English, whether they belong to independent colleges, higher vocational schools or key universities. This result is very easy to understand; on one hand, as a non-English major, it is impossible to learn English for a whole day. It is impossible for students to spend too much time in a single subject public class, which is not conducive to the development of students' comprehensive quality. On the other hand, the investment in time would be very sufficient if the student persists in learning English for one hour every day after class, otherwise it will affect the study of students' professional courses.

In addition, due to the different levels of English enrollment, students' study time is slightly different. In general, very few students can spend more than 2 hours studying a public class. In other words, students won't spend more than 2 hours on English learning if they don't have a deep interest in English. In addition, students with a poor foundation are more willing to spend more time studying to make up for their own shortcomings.

And it is shown that if TEM 4 grades are used to measure students' learning outcomes, in general, the more time and energy you spend on English learning, the higher your academic performance will be. Students with a poor English foundation can also achieve better learning outcomes by investing a lot of time and energy.

If the absolute time spent on English learning by students from key universities is measured by students from key universities, it can be seen that the English level of students from key universities is much higher than that of students from independent colleges. In terms of average scores, the difference is 31 points. However, the time spent by independent college students in English learning is the same as that of key university students. In other words, independent college students don't invest extra time to make up for their own shortcomings in the case of backward scores. As a result, they will lag far behind in English learning.

Since students only spend less than an hour a day on English, how do independent college students use and allocate their spare time? The distribution and use of extracurricular time for students were also investigated. The results are as follows:

\section{B. Extracurricular Time Allocation and Utilization}

In the questionnaire, students' free time allocation is divided into six categories: entertainment, including surfing the Internet, playing games, playing mobile phones, sleeping, shopping, falling in love and hanging out; learning, including reading books inside and outside the class, on-line learning; practice, such as society activities, student union activities, part-time jobs, faculty activities and internships; textual examination; sports and the others. The following three tables reflect the proportion of the number of students engaged in the main activities after school and the proportion of time allocation.

TABLE IV. INDEPENDENT COLLEGE STUDENTS' EXTRACURRICULAR TIME SCHEDULE AND UTILIZATION

\begin{tabular}{lllllll}
\hline Extracurricular activities & Entertainment & Study & Social practice & Textual examination & Sports & Others \\
\hline Student number & $92.8 \%$ & $75.3 \%$ & $66.4 \%$ & $36.3 \%$ & $48.2 \%$ & $18.1 \%$ \\
Time ratio & $25 \%$ & $18.8 \%$ & $18.8 \%$ & $12.5 \%$ & $12.5 \%$ & $12.5 \%$ \\
\hline
\end{tabular}

TABLE V. EXTRACURRICULAR TIME SCHEDULE AND UtILIZATION OF KEy UNIVERSITY STUDENTS

\begin{tabular}{lllllll}
\hline Extracurricular activities & Entertainment & Study & Social practice & Textual examination & Sports & Others \\
\hline Student number & $96.1 \%$ & $92.3 \%$ & $73.9 \%$ & $9.55 \%$ & $47.1 \%$ & $17.8 \%$ \\
Time ratio & $25 \%$ & $25 \%$ & $12.5 \%$ & $12.5 \%$ & $10.6 \%$ & $14.4 \%$ \\
\hline
\end{tabular}

TABLE VI. EXtracurricular Time Schedule ANd Utilization OF STUdENTS IN Higher Vocational Schools

\begin{tabular}{lllllll}
\hline Extracurricular activities & Entertainment & Study & Social practice & Textual examination & Sports & Others \\
\hline Student number & $88.7 \%$ & $74.2 \%$ & $49.2 \%$ & $29 \%$ & $48.4 \%$ & $22.5 \%$ \\
Time ratio & $25 \%$ & $18.8 \%$ & $18.8 \%$ & $12.5 \%$ & $12.5 \%$ & $12.5 \%$ \\
\hline
\end{tabular}

In the questionnaire (see "Table IV", "Table V" and "Table VI") the surveyed students were asked to select the main activities they engaged in their spare time and the proportion of activities in their spare time. From the above results, the lifestyle of contemporary college students has undergone tremendous changes. In the era of entertainment 
for all, entertainment and relaxation have become the mainstream of life. The vast majority of students take out a quarter of their time each day for entertainment and relaxation.

After comparing the proportion of students in the three schools who used their spare time to study, it is found that the proportion of the people had a big difference. In independent colleges and higher vocational schools, about $24 \%$ of students say that they don't study after school every day; while in key universities, only $7 \%$ of students say that they don't study outside the classroom every day. In addition, as can be seen from the above table, the proportion of time spent by independent college students in learning is lower than that of key university students, and less than $19 \%$ of the spare time of independent college students is spent on learning. Compared with students from key universities, students from independent colleges seem to put less emphasis on their study in their spare time.

In addition, it is found that in terms of social practice, students from independent colleges and key universities maintain the same level, while students from vocational colleges have a lower participation rate. The reason is related to the independent college's emphasis on student associations and social practice. In addition, we can also see that the time spent by independent college students in social practice is much higher than that of key university students, which will undoubtedly affect the proportion of students' extracurricular study time.

In terms of textual examination, independent college students seem to be more enthusiastic than key university students. The reason may be that independent college students are more willing to strengthen their competitiveness in the job market through various qualifications and diplomas.

\section{Professional Class Study Time}

In order to fully understand the learning situation of independent college students, the author also investigated the professional class time of students. The results are as follows:

TABLE VII. Survey of COLlEge Students' Study Time For SPECIALIZED Courses Every Day

\begin{tabular}{llllll}
\hline \multicolumn{1}{c}{ Learning time } & $<\mathbf{3 0}$ minutes & $\mathbf{3 0 - 6 0}$ minutes & $\mathbf{6 0 - 9 0}$ minutes & $\mathbf{9 0 - 1 2 0}$ minutes & $>$ 120 minutes \\
\hline Independent college & $24.6 \%$ & $47.9 \%$ & $16.9 \%$ & $10.6 \%$ & \\
Key university & $13.8 \%$ & $28.3 \%$ & $21.7 \%$ & $14.5 \%$ & $21.7 \%$ \\
Higher vocational school & $20.4 \%$ & $32.8 \%$ & $27.8 \%$ & $5.7 \%$ & $13.1 \%$ \\
\hline
\end{tabular}

It can be seen from the results (see "Table VII") that nearly $57 \%$ of key university students spend more than one hour in class to study professional courses, and more than $20 \%$ of students study professional courses for more than two hours. In the independent college, $70 \%$ of students spend less than one hour in professional courses, and more than $20 \%$ spend less than 30 minutes on their major courses. In addition, compared with higher vocational schools, the average time for independent college students to study professional courses is also less than that of higher vocational students.

\section{Lifestyle (Extracurricular Time and Mobile Phone Usage)}

In order to gain a deeper understanding of the lifestyle of contemporary college students, we investigated the time students go to bed at night and how long they use their mobile phones.

The results (see "Table VIII" and "Table IX") showed that $90 \%$ of students went to bed after $11 \mathrm{pm}$ and a third delayed going to bed until after midnight. And most students spend a lot of time on their mobile phones every day.

TABLE VIII. SURVEY OF COLLEGE STUDENTS' EVERY-DAY SLEEPING TIME

\begin{tabular}{lllll}
\hline \multicolumn{1}{c}{ Learning time } & Before 22 o'clock & 22 to 23 o'clock & 23 to 24 o'clock & After 24 o'clock \\
\hline Independent college & 1.3 & 9.5 & 54.8 & 35.1 \\
Key university & 0 & 6.4 & 55.8 & 37.8 \\
Higher vocational school & 0.8 & 9.6 & 58.4 & 31.2 \\
\hline
\end{tabular}

TABle IX. Time Survey of College Students Using Mobile Phones Every Day

\begin{tabular}{lllll}
\hline \multicolumn{1}{c}{ Learning time } & \multicolumn{1}{c}{ 1 hour } & $\mathbf{1 - 2}$ hours & $\mathbf{2 - 3}$ hours & More than 3 hours \\
\hline Independent college & 1.7 & 8.4 & 29.3 & 60.6 \\
Key university & 3.2 & 26.9 & 39.7 & 30.1 \\
Higher vocational school & 1.6 & 5.6 & 30.9 & 61.3 \\
\hline
\end{tabular}

Mobile phones can be said to have become an indispensable part of college life. So what do college students mainly do with their mobile phones? The functions of mobile phones can be divided into six categories: First, life-related, including online shopping, online booking, etc., such as ordering train tickets, airline tickets and hotels; second, entertainment activities, that is, using mobile phones to listen to music, play games, etc.; third, communication, such as phone calls, online chat, microblogging and WeChat; fourth, learning, such as checking information and Internet courses; fifth, access to information, such as reading domestic and foreign news or related information; six, others. 
The table below clearly shows the proportion of people who use mobile phones for various activities.

TABle X. Survey of College Students Using Mobile Phones

\begin{tabular}{lllllll}
\hline & Life-related & Entertainment & Communication & Study & Access to information & Others \\
\hline Independent college & $80.2 \%$ & $91.8 \%$ & $91.8 \%$ & $78.7 \%$ & $51.9 \%$ & $15.9 \%$ \\
Key university & $73.1 \%$ & $91.0 \%$ & $96.8 \%$ & $83.3 \%$ & $51.9 \%$ & $51.9 \%$ \\
Higher vocational school & $73.6 \%$ & $89.3 \%$ & $91.7 \%$ & $84.2 \%$ & $51.7 \%$ & $18.2 \%$ \\
\hline
\end{tabular}

As can be seen in "Table X", college students use mobile phones for a variety of activities. Mobile phones have invaded most of the students' lives, and have become an inevitable tool for student life and learning.

\section{THE RESULTS OF DISCUSSION}

Through the questionnaire, the extracurricular English learning status and amateur life arrangements of independent college students are better understood. As English teachers, we should make effective changes in the teaching methods and effective methods of learning according to the students' learning and life characteristics.

\section{A. Status Quo of Independent College Students' Study}

Through the investigation of students' leisure activities and extracurricular English study time, it is found that independent college students don't attach importance to extracurricular learning and don't invest time. In addition, there is no correct understanding and mastery of the learning methods of English subjects.

First, the survey shows that independent college students don't value extracurricular learning. At present, the mainstream of college students' spare time life no longer puts study in the first place as it did ten or twenty years ago. Entertainment has occupied a quarter of the college students' spare time and this phenomenon has appeared in universities of all levels, and even key universities are inevitable. However, in the allocation of spare time, key university students can balance the ratio of their own learning with other extracurricular activities, so that learning and entertainment can be listed as the mainstream of extracurricular life. Independent college students, however, not only spend a lot of time on recreational activities, but also continually squeeze the time of study to engage in nonlearning activities. Moreover, under the premise that the foundation of learning itself is not reliable, it's impossible for students to invest time and energy in learning to make up for their own shortcomings.

Although the current state emphasizes the quality education of students, the long-term development of students' comprehensive ability still needs to be built on the basis of students' good grasp of professional and general knowledge. If the basic and professional study is neglected, the quality education and comprehensive ability of the students will be cultivated like a fish without water and a flower without roots. For example, independent college students often reflect their weak knowledge structure, narrow knowledge and lack of competitiveness in the field when they participate in various competitions. Therefore, students' attitudes of not paying attention to learning will affect their long-term development.

In addition, students don't invest enough time and energy in their studies. It can be seen through the survey that independent college students spend less time and energy in both professional and public English than other universities. And, unfortunately, many students spend less than 30 minutes a day on English learning compared to professional classes.

Finally, students don't have a correct understanding of the way English is learned. Learning a foreign language such as English in a non-verbal environment requires learners to actively learn outside the classroom and give play to the learner's subjective initiative. Mr. Lv Shuxiang emphasizes that English learning needs four aspects: eyes, ears, hands and mouths. For English learning, students not only should grasp grammar learning, have a lot of memory and accumulation, but also should have the ability to speak and listen. Compared with students' professional courses and other public lessons, English requires learners to constantly remember and accumulate language materials, such as vocabulary. A large number of memories require repeated review and repetition. Students should read aloud, and input a lot of reading and listening materials. It is not enough to achieve good academic goals by taking 4-6 English lessons per week. Learners need to arrange their own study time. In addition, in classroom teaching, teachers should give more guidance on language input and methods, but whether students can fully absorb the language content output by teachers depends on their learning attitude and whether they can really achieve the "four aspects" mentioned above. But from the ordinary classroom teaching and the interaction between teachers and students, most students in independent colleges can't meet the above basic requirements.

At the same time, some students in independent colleges haven't formed correct and good learning habits, such as taking notes, preview before class, and review after class and regular reflection, etc., so they will encounter great difficulties in learning English. Although the students listen carefully in class, if they fail to review after class, the language materials acquired in class, such as vocabulary, phrases and sentence structures, will be gradually forgotten. Therefore, English is not like math class. You only need to understand the formulas and theorems learned in class to solve all kinds of question types and problems encountered. English emphasizes continuous accumulation and review. If the content in the first class is not effectively consolidated and reviewed after class, it will affect the understanding and learning of the next class. In the long run, students will find 
that despite having English classes every week, there is no practical result at all. This may lead to students' loss of interest in learning and they may not be willing to learn English anymore.

Therefore, if students want to learn English well, they need to have a correct understanding of the English learning process and methods, do a good job in psychological construction, and constantly review after class, actively accumulate language knowledge, do not take shortcuts, truly master the language skills and improve self-competition ability.

\section{B. The Enlightenment to Teaching}

1) Changes in students' lifestyles and learning styles require teachers to improve their teaching methods: Against the new era, new requirements and new situations, the learning life and learning style of contemporary college students are constantly changing. The requirements of teachers for students can no longer be emphasized as hard as they did ten years ago. Due to the extremely developed social information nowadays, students don't need to learn all kinds of knowledge by rote. They can use the network, and this kind of knowledge will appear in front of them in detail. Students are especially good at this kind of tools. For English learning, if students see some English words or English chapters, a variety of translation software can translate the information you need. Although the translation of translation software is not very accurate according to the research of linguists, it is enough for students who need to know some information. Therefore, in order to promote students' learning, through examinations and quizzes driven, students are compulsively required to memorize some common knowledge and English words in order to enhance their learning by surprise.

Mobile phones and networks play an important role in student life. Various online learning and classroom management software are also emerging along with time. Although it is necessary to further study the application effect of such software in classroom teaching, this software can play a certain role in answering questions or assignments and group discussions outside the classroom.

In addition, teachers can develop online forums and discussions and require students to discuss the prescribed topics at the specified time, and the evaluation scores of teachers can help students apply what they want to practice. In normal times, vocabulary learning, reading comprehension and other small tasks can be published in the We-Chat group in real time, and students are required to complete and record the results.

Therefore, under the new teaching situation, teachers must adhere to the principle of teaching without class and teaching students in accordance with their aptitude, and update their teaching ideas and methods so as to meet the needs of students and achieve the goal of teaching and educating.
2) Stimulating students' attitudes and interests in English learning: Through the survey, it's found that students' learning attitude is arbitrary and their interest in learning is not strong, especially the interest in English learning is low and their attitude is unconcern. Moreover, many students have low English proficiency at the time of enrollment, and they have always believed that their English foundation is weak; therefore, once the content of the teacher's class exceeds their own understanding, the students will have fear and give up learning. In addition, even if students know about their actual conditions, in their spare time, they don't want to spend more time to learn English. Some students are not clear about what they should learn or how they learn in self-study time and in view of this situation, teachers should fundamentally understand students' needs for English and design courses according to Krashen's "N+1 acquisition theory" according to students' actual learning level. Teachers should not be too strict with students so that students can have faith in their English learning. In addition, in classroom teaching, teachers should think of more ways and make more efforts to carefully design the teaching links, with diverse activities in line with the actual conditions of students, and enable students to apply what they have learned, generate interest independently and stimulate internal development power.

3) Developing students' good study habits and learning awareness with an effort: At present, China's education faces very severe difficulties. A variety of educational thoughts are intertwined. Schools, teachers and parents have different goals and requirements for the cultivation of students. But fundamentally speaking, whether it is for exam-oriented education or quality education, good study habits and awareness will have an important impact on students' current and future. Independent college students have failed to lay a solid foundation of knowledge in primary and secondary education, and have not developed good study habits and concepts. Therefore, in daily teaching, teachers should pay attention to students' cultivation of learning methods and concepts, and cooperate with teaching and counselors to do a good job in students' independent learning supervision, so as to help students rebuild their confidence in learning, develop good learning habits and establish correct learning awareness.

\section{CONCLUSION}

Due to the particularity of English subjects, the effectiveness of English learning is highly demanding for students' independent learning. Therefore, it is of great significance to fully understand the students' learning status to correctly guide students' learning. Through the survey, it is found that the status of English learning of independent college students is not optimistic, and the attitude towards learning is also quite different from that of college students of the same age. The time and number of students studying outside the classroom are also lower than those of other universities. Therefore, in the face of such a severe situation, 
as English teachers, it is suggested that you should give more guidance on students' learning attitudes, habits, and learning methods. In addition, you also need to adjust English teaching methods accordingly to adapt to the new teaching situation.

\section{REFERENCES}

[1] Littlewood William. The second and foreign language learning[M]. Foreign Languages and Research Press, 2004. (in Chinese)

[2] Lu Shuxiang. Learning English for Chinese[M]. China Social Sciences Press, 2005. (in Chinese)

[3] Zeng Hongqiang. Investigation and Thinking on the Utilization of College Students in Extracurricular Time[J]. Journal of Educational Science of Hunan Normal University, 2007. (in Chinese) 